Н. В. Литвиненко, В. М. Гладка, Т. Й. Пурденко, Г. Я. Силенко, В. А. Пінчук Вищий державний навчальний заклад України "Українська медична стоматологічна академія”, м. Полтава

\title{
ОСОБИСТІСТЬ ВИКЛАДАЧА ВИЩОГО МЕДИЧНОГО НАВЧАЛЬНОГО ЗАКЛАДУ ЯК ЦЕНТРАЛЬНА ФІГУРА В МОДЕРНІЗАЦІЇ ОСВІТИ В УKРAÏHI
}

\author{
N. V. Lytvynenko, V. M. Hladka, T. Y. Purdenko, H. Ya. Sylenko, V. A. Pinchuk \\ Higher State Educational Establishment "Ukrainian Medical Stomatological \\ Academy", Poltava

\section{THE IDENTITY OF LECTURER AT HIGHER MEDICAL INSTITUTION UKRAINE} \\ AS A CENTRAL FIGURE IN THE MODERNIZATION OF EDUCATION IN
}

\begin{abstract}
Мета роботи - акцентувати увагу на застосуванні інноваційних технологій у професійному розвиткові викладача вищого медичного закладу у вигляді вдосконалення його комунікативних здібностей та активної творчої співпраці зі студентами.

Проведено аналіз літературних джерел та власного досвіду роботи щодо впровадження в навчально-виховний процес нових педагогічних технологій з акцентом на педагогічне спілкування, інноваційних методик викладання із застосуванням методики “зворотного зв’язку”, проведення сумісної роботи викладача і студента в неврологічному відділенні, спільної освітньої роботи серед населення.

Основна частина. На кафедрі нервових хвороб $з$ нейрохірургією та медичною генетикою ВДНЗУ “УМСА” велика увага приділяється удосконаленню комунікативних здібностей професорсько-викладацького складу у вигляді вдосконалення психологічної компетентності у педагогічній діяльності та активної співпраці зі студентами: це сумісні огляди хворих неврологічного відділення з обговоренням проблемної ситуації, використанням таких методик інтерактивного навчання, як ділова гра та “мозковий штурм”, проведення майстер-класів - з електроенцефалографії, реоенцефалографії, електронейроміографії, освітня робота серед населення, створення інформаційних плакатів, проведення опитування студентів медичного та стоматологічного факультетів стосовно “зворотного зв’язку” з викладачем на практичних заняттях та лекціях.

Висновки. Десятирічний досвід застосування даної методики проведення занять дозволив підвищити ефективність навчального процесу. Студенти мають змогу отримати не лише теоретичну підготовку, а й в обов'язковому порядку оволодіти практичними навичками, що сприяє поліпшенню розуміння та засвоєння матеріалу, розвитку клінічного мислення.

У медичній освіті саме така інтеграція дозволить консолідувати професійно-педагогічну громадськість на розробку більш досконалих стандартів і умов освітньої діяльності, основним результатом якої буде формування компетентної, професійно і соціально мобільної особистості випускника медичного вузу, здатного до безперервного професійного розвитку в просторі своєї лікарської діяльності.
\end{abstract}

Ключові слова: медична освіта; викладач; спілкування; професіоналізм; модернізація.

The aim of the study - to focus on the application of innovative technologies in the professional development of lecturers at higher educational medical institution by means of improving their communication skills and active creative collaboration with students.

The literature and our own experience as to the implementation of new educational technologies in the educational process with a focus on instructional communication, innovative teaching methods, using the techniques of "feedback", collaboration of lecturer and students at Neurology department, joint educational activities among the population are analyzed.

The main body. The staff of the Department of Nervous Diseases with Neurosurgery and Medical Genetics of Higher State Educational Establishment "Ukrainian Medical Stomatological Academy” focuses on improving the communication skills of lecturers by means of enhancing the psychological competence in teaching activities and active cooperation with students: this is represented by joint examination of patients of neurological department, discussion of problematic situations, using techniques such as interactive learning, "business games", "brainstorming” and "workshops" on electroencephalography, rheoencephalography, electroneuromyography, educational work among the population, developing posters, interviewing students of medical and dental faculties as to the "feedback" with the lecturer during workshops and lectures.

Conclusion. Ten years of experience with this technique for delivering sessions allowed to increase the effectiveness of the educational process. Students can receive not only theoretical knowledge but necessarily learn practical skills that improve understanding and learning outcomes, promote the development of clinical thinking.

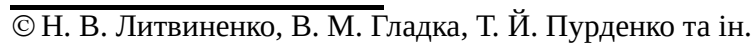


In medical education, such integration will consolidate the professional training to develop improved standards and conditions for educational activities, the main result of which will be forming a competent, professionally and socially mobile individual - graduate of medical institution, capable of continuing professional development in the specific area of medical practice.

Key words: medical education; lecturer; communication; professionalism; modernization.

Вступ. Система медичної освіти в Україні сьогодні - та галузь, що найбільш реформується, а оцінки реформ - дуже суперечливі.

Однією з актуальних проблем вищої медичної освіти є забезпечення підготовки випускників, готових до діяльності лікаря в сучасних, досить складних, умовах. При вирішенні завдання підвищення якості підготовки фахівців потрібно звернути пильну увагу на підготовку та професійний розвиток викладача вузу, який вже не може бути тільки передавачем знань та інформації, він повинен бути і педагогом, і психологом, і психотерапевтом $[1,5]$. Саме викладач, на наш погляд, $є$ центральною фігурою в модернізації сучасної освіти.

Мета роботи - застосування інноваційних технологій у професійному розвиткові викладача вищого медичного закладу на кафедрі нервових хвороб з нейрохірургією та медичною генетикою у вигляді удосконалення комунікативних здібностей викладача, активної творчої співпраці зі студентами.

Проведено аналіз літературних джерел та власного досвіду роботи щодо впровадження в навчальновиховний процес нових педагогічних технологій 3 акцентом на педагогічне спілкування, інноваційних методик викладання з застосуванням методики “зворотного зв'язку”, проведення сумісної роботи викладача і студента в неврологічному відділенні, спільної освітньої роботи серед населення.

Основна частина. Реалізуючи важливу соціальну функцію - підготовку фахівця вищої кваліфікації, викладач зобов'язаний сам бути професіоналом високого класу, володіти інформацією не тільки 3 навчальної дисципліни, що викладається, а й знати новітні наукові розробки та практичні рішення в його предметній галузі.

Викладач вузу, з одного боку, проводить науководослідну роботу, розробляє методичний інструментарій освітнього процесу. Отже, досягнення ним високого рівня професіоналізму лежить в області “людина - наука”. 3 іншого боку, він здійснює суто педагогічну діяльність, виступає як методист освітнього процесу, а його професійна діяльність відноситься до системи “людина - людина” [2]. Робота педагога включає засвоєння і впровадження в навчально-виховний процес нових педагогічних технологій, інноваційних методик викладання, створення навчальних посібників для студентів і методичних розробок для викладачів. Тільки викладач, що володіє професійними і загальними компетенціями, зможе підготувати випускника не тільки до професійної діяльності, а й сприятиме формуванню його особистісних якостей і підготувати його до самоосвіти та самовиховання [3].

Викладач для успішної роботи повинен мати необхідну психологічну підготовку, в якій виділяють три основних компоненти: формування психологічної культури (турбота людини про своє психологічне здоров’я, культуру поведінки та спілкування), психологічну компетентність у педагогічній діяльності (знання і вміння з психології, необхідні для вирішення професійних завдань у педагогічній діяльності) i вміння людини представляти себе на ринку праці [3].

У зв'язку з цим викладачеві бажано володіти педагогічним талантом і необхідно формувати високий рівень педагогічної майстерності, професійної педагогічної компетентності, основною складовою якої є педагогічне спілкування.

Спілкування - це джерело і канал інформації. При цьому в процесі спілкування людина набуває і передає не тільки ідеї, факти, уявлення, але і ціннісне ставлення, інтереси, настрої, почуття. При цьому здійснюється раціональна, емоційна та вольова взаємодія педагога й учнів, лікаря і пацієнта, виявляється і формується спільність поглядів, думок, настроїв, досягається взаєморозуміння, здійснюється передача й засвоєння знань та досвіду, створюються згуртованість і солідарність [4]. Педагогічне спілкування відіграє чималу роль у формуванні та передачі соціальних установок, ставлення до пацієнтів, способу життя. Всі групи здібностей, необхідних викладачеві (загальнокультурні, пізнавальні, проектувальні та організаторські), замикаються на здібностях комунікативних. Адже спілкування - одна з форм співтворчості, в процесі якого людина пізнає і перетворює навколишній світ. Здійснюється прагнення особистості до реалізації своєї соціальної ролі, своїх організаторських і партнерських якостей.

Хороший викладач-клініцист повинен стати для студентів еталоном, ідеалом його майбутньої про- 
фесії. Такий викладач може передати стиль свого клінічного мислення, манеру і прийоми практичних дій, методи реалізації деонтологічних принципів, адже для студентів соціально-психологічним аспектом вибору професії є мотив - бути прийнятим (включеним) у дану професійну групу.

На кафедрі нервових хвороб з нейрохірургією та медичною генетикою серед студентів досить популярні клінічні розбори хворих, коли викладач разом зі студентами та іншими співробітниками клініки бере участь в огляді хворих, сумісно обговорюючи проблемні ситуації, використовуючи такі методики інтерактивного навчання, як ділова гра та "мозковий штурм”. За участю студентів на кафедрі проводяться майстер-класи: електроенцефалографія, реоенцефалографія, електронейроміографія. В кінці навчального року частина студентів виступає на студентській конференції із доповідями, над якими вони працювали із своїми науковими керівниками. Декілька років поспіль студенти сумісно з завідувачем кафедри та викладачами беруть активну участь у проведенні Дня інсульту: в бібліотеках, торгових центрах, на виставках вони проводять освітню роботу серед населення, створюють інформаційні плакати з вказанням факторів ризику інсульту, методів його профілактики, проводять масове вимірювання артеріального тиску мешканцям міста. При цьому, спілкуючись з іншими людьми, аналізуючи їх ставлення до себе, і студент, і викладач виявляють потребу в самовдосконаленні та реалізують цю потребу в процесі саморозвитку.

На кафедрі нервових хвороб з нейрохірургією та медичною генетикою ВДНЗУ “УМСА” кожен рік проводиться опитування студентів медичного та стоматологічного факультетів: комунікативні здібності викладачів і їх компетентність у спілкуванні особливо цінуються студентами 4 курсу, які більшою мірою, ніж студенти 5-6 курсів, у своїх оцінках викладачів виділяють їх особисті якості.

На жаль, у даний час авторитет викладача серед студентів невисокий. При опитуванні студентів лише 68 \% змогли назвати серед своїх викладачів таких, чиї людські та професійні якості збігаються з їх уявленнями про образ фахівця-медика.

3 якостей, які сучасні студенти найбільше цінують у викладачах, зазвичай називають широкий кругозір, знання і захопленість предметом, інтерес до особистості студента, розуміння, співчуття, повагу, терпимість, доброзичливість, справедливість. Серед негативних якостей часто виділяють низький рівень культури, нетерпимість, фальш, принижен- ня гідності студента, зарозумілість, жорстокість, злість. Студент хоче, щоб його розглядали не як учня, а як майбутнього колегу.

Думка викладача про певного студента і його здібності може вплинути на самооцінку і поведінку учня. Викладач на основі свого досвіду формує свою стратегію поведінки по відношенню до даного студента. Останній, відштовхуючись від стратегії викладача, від його суб'єктивної думки, будує свою власну поведінку. Якщо викладач - авторитетна людина, студент буде намагатися вписатися в ту модель поведінки, яку йому запропонували, i “стереотип очікування” збудеться. Можуть бути як позитивні, так і негативні наслідки. Останнє відбувається в разі, якщо думка викладача про студента або його здібності негативна.

Одним з основних секретів ефективного спілкування $є$ вміння “правильно” слухати співрозмовника. “Секрет впливу на людей - не в умінні говорити, а в умінні бути хорошим слухачем, - писав Дейл Карнегі. - Багато людей, намагаючись переконати когось у своій правоті, занадто багато говорять самі. Дайте висловитися іншим людям”. Одним із найбільш важливих моментів у будь-якому спілкуванні $\epsilon$ момент зворотного зв'язку, завдяки якому співрозмовник відчуває, що він говорить 3 живою людиною, а не в порожнечу, і до того ж дізнається, як саме його почули і зрозуміли. При цьому в будь-якому висловлюванні існують принаймні два рівні: інформаційний і емоційний. Отже, зворотний зв'язок може бути двох видів - відображення інформації і відображення почуттів. Вид слухання, в якому на перший план виступає відображення інформації, називають активним слуханням. Активне слухання передбачає постійне відображення змісту тієї інформації, яку передає Вам співрозмовник. Найбільш загальноприйнятими прийомами активного слухання є уточнення правильності розуміння повідомлення шляхом питань типу: "Чи правильно я Вас зрозумів, що ...”; парафраз: “Таким чином, Ви хочете сказати ...” або “Іншими словами, Ви мали на увазі ...” Застосування таких, на перший погляд, простих прийомів спілкування забезпечує адекватний зворотний зв'язок: у Вас і Вашого співрозмовника з'являється впевненість у тому, що ви правильно зрозуміли один одного, а також непрямим чином інформувати співрозмовника про те, що перед ним рівний йому партнер. Дані підходи широко обговорюються в педагогічному колективі кафедри.

Викладачеві необхідний зворотний зв'язок 3 боку студентів щодо його особистих якостей і дій 
на навчальну групу. Це перешкоджає виникненню професійних і особистісних деформацій педагога. Небезпека подібних деформацій виникає у досвідчених педагогів i, як правило, не загрожує їх колегам-початківцям. До таких деформацій можуть бути віднесені: виникнення мовних і розумових стереотипів як результат багаторазового повторення однієї і тієї ж інформації; неадекватна завищена самооцінка викладача - розплата за вже накопичений педагогічний досвід i, як її результат, виникає схильність триматися старих методів, нечутливість до того, що вони вже неадекватні новим цілям, новому змісту і, найголовніше, не сприймаються студентами - іншим поколінням із новими соціальними потребами. Деформація відносин між педагогом і учнем характеризується формалізмом, байдужістю і часто неповагою один до одного, взаємним нерозумінням і відсутністю бажання зрозуміти іншого. Дана ситуація є результатом того, що відносини між педагогом і студентом будуються лише $з$ приводу навчального предмета і не зачіпають інших сторін особистості і буття студентів.

Особистісний підхід стає ефективним, якщо педагог у кожному студенті бачить унікальну особистість, у якій необхідно розвивати свідомість власної неповторності й одночасно причетності до соціального цілого. Тільки той, хто бачить і цінує особистість у собі, зможе побачити і прийняти особистісні особливості кожного з оточуючих його людей: колег, студентів, пацієнтів.

Найбільш суттєвою, з точки зору успішності діяльності педагога, є такі моменти взаємодії, як вміння вислухати думку студента, справедливість, вміння організувати роботу студентів з повною віддачею, виховання відповідального ставлення до навчальної діяльності, вміння відчувати настрій студентів і підбадьорювати їх, якщо щось не виходить (боязнь курації, невпевненість, страх). Чим адекватніше педагог може уявити перераховані особливості взаємин, тим вище задоволеність студентів щодо процесу навчання, тим вище авторитет викладача.

Висновки. Сьогодні розширюється самостійність медичних навчальних закладів у розробці власних інноваційних методик розвитку, надання викладачам права самостійно вибирати форми, методи, засоби навчання і технологію навчального процесу. Але одночасно підвищується відповідальність за якість освіти.

Для роботи в медичному вузі викладачеві необхідні певні якості особистості, головні з яких - любов до педагогічної діяльності, ерудиція, любов до студентів, високий рівень культури і моральності, порядність, справедливість і доброзичливість. Без будь-якої з цих якостей успішна педагогічна робота неможлива. Але крім необхідності природних задатків, необхідна постійна робота викладача над собою. Від цього багато в чому залежать і успішність його педагогічної діяльності, і його авторитет.

У медичній освіті саме така інтеграція дозволить консолідувати професійно-педагогічну громадськість на розробку більш досконалих стандартів і умов освітньої діяльності, основним результатом якої буде формування компетентної, професійно і соціально мобільної особистості випускника медичного вузу, здатного до безперервного професійного розвитку в просторі своєї лікарської діяльності.

Надалі ми плануємо вивчати ефективність спілкування студент-викладач шляхом створення i впровадження спеціальних анкет-опитувальників для студентів і викладачів, у яких також будуть враховуватися побажання студентів у плані удосконалення комунікацій.

\section{Список літератури}

1. Інтеграція вищих медичних навчальних закладів України із системою європейської освіти / Н. В. Литвиненко, В. А. Пінчук, А. М. Кривчун [та ін.] // Європейський вибір - невід'ємна складова розвитку вищої медичної освіти України : матеріали навч.-метод. конф. Полтава, 2013. - С. 112-114.

2. Мусихин И. А. Современные подходы в проведении мониторинга качества результатов образования в вузе / И. А. Мусихин, В. Б. Жарников // Вестник СГГА. - 2013. Вып. 1 (21). - С. 113-122.

3. Русина Н. А. Компетентностный подход в системе высшего медицинского образования / Н. А. Русина // Высшее образование в России. - 2010. - № 2. C. 100-107.

4. Щербатых А. В. Компетенции преподавателя медицинского вуза / А. В. Щербатых, Л. Ю. Хамнуева // Сибирский медицинский журнал. - 2010. - № 7. - С. 95-96.

5. Ларионова М. В. Преподаватель вуза - субъект модернизации образования / М. В. Ларионова // Высшее образование в России. - 2007. - № 12. - С. 30-33. 


\section{References}

1. Lytvynenko, N.V., Pinchuk, V.A., Kryvchun, A.M., Sylenko, H.Ya., Tarianyk, K.A., Hladka, V.M., ... Purdenko, T.Y. (2013). Intehratsiia vyshchykh medychnykh navchalnykh zakladiv Ukrainy iz systemoiu yevropeyskoi osvity [Integration of higher educational institutions of Ukraine with European education system]. Yevropeyskyi vybir - nevidiemna skladova rozvytku vyshchoi medychnoi osvity Ukrainy: materialy navchalno-metodychnoi konferentsii [European choice - an integral part of higher medical education in Ukraine: materials of conference], (pp. 112-114). [in Ukrainian].

2. Musikhin, I.A., \& Zharnikov, V.B. (2013). Sovremennyye podkhody $\mathrm{v}$ provedenii monitoringa kachestva rezul'tatov obrazovaniya v vuze [Modern approaches in monitoring the quality of educational outcomes in the university]. Vestnik SGGA - Bulletin of SSGA, 1 (21), 113-122 [in Russian].
3. Rusina, N.A. (2010). Kompetentnostnyy podkhod v sisteme vysshego meditsynskogo obrazovaniya [Competence approach in the system of higher medical education]. Vyssheye obrazovaniye $v$ Rossii - Higher education in Russia, 2, 100-107 [in Russian].

4. Shcherbatykh, A.V., \& Khamnuyeva, L.Yu. (2010). Kompetentsii prepodavatelya meditsynskogo vuza [Competences of the medical university lecturer]. Sibirskiy meditsinskiy zhurnal - Siberian Medical Journal, 7, 95-96 [in Russian].

5. Larionova, M.V. (2007). Prepodavatel' vuza - subyekt modernizatsii obrazovaniya [The lecturer of the university is the subject of education modernization]. Vyssheye obrazovaniye $v$ Rossii - Higher education in Russia, 12, 30-33 [in Russian]. 